\title{
Impact of Customer Value, Brand Image and Product Attributes to Satisfaction and Loyalty Tourism Visitors in Jember Regency
}

\author{
Dr. Nurul Qomariah, MM \\ Economic Faculty Universitas Muhammadiyah Jember
}

Doi: 10.2478/mjss-2018-0105

\begin{abstract}
This study aims to determine the impact of customer value, brand image and product attributes to the satisfaction and loyalty of visitors on the existing coastal tourism in Jember Regency which includes Papuma Beach, Watu Ulo Beach, Payangan Beach, Puger Beach and Paseban Beach and Bande Alit Beach. The population of this study is all visitors of coastal tourism in Jember District. Sampling method is purposive sampling with total sample as many as 300 respondents. With the number of respondents each beach tour amounted to 50 respondents. Quantitative analysis using multiple regression analysis. The result of validity test and reliability test indicate that measuring instrument can be used well. Hypothesis test shows that customer value, brand image and product attribute have an effect on visitor satisfaction. The value of the customer does not affect the loyalty of visitors, while the brand image, product attributes and visitor satisfaction affect the loyalty of visitors.
\end{abstract}

Keywords: customer value, brand image, tourism product attributes, visitor satisfaction, visitor loyalty, beach tourism

\section{Introducion}

Tourism is an industrial activity capable of generating rapid economic growth, especially in the provision of jobs, income increase, standard of living and stimulus for other fields. The tourism sector is one of the strategic industries and has become one of the largest industrial sectors in the world. The tourism industry is one of the industries that contributes $10 \%$ to $20 \%$ of the state revenue (Martaleni, 2010). Along with the increasing economic growth and with the increase of society's income hence society need for tourism services also increase. Thus the competition in the tourism service industry is even increasing. The management of the tourism industry is required to always pay attention to the value of customers in an effort to improve the quality of service. By paying attention to customer value, customer satisfaction is expected to increase so that the sustainability of the tourism industry will be guaranteed in the future (Qomariah and Hanafi, 2014).

In the current era of globalization, the tourism sector is the largest and strongest industry in financing the global economy. The tourism industry proved immune from the global crisis. As the global economy tumbles, tourism growth in Indonesia continues to grow, even exceeding the national economic growth rate. The growth of tourism industry in Indonesia in 2014 reached 9.39 percent higher than the previous year. That figure is above the national economic growth which reached 5.7 percent. The tourism sector will really be a reliable economic leverage (Martaleni, 2010). Indonesia's current socio-economic situation and conditions show that the decline in agricultural land and other employment and environmental degradation due to manufacturing activities and other economic activities that exploit natural resources, tourism should be developed as one of the mainstay industry sources. The tourism sector in addition to increase economic growth, will also damage the environment and otherwise stimulate environmental conservation. 
This is understandable because the development of tourism can not be separated from the environment as one of the means or attractions. From the Word Tourism Organization (WTO) report and analysis, it is found that tourism contribution is very important for job creation. The strength of Indonesia's main tourism industry is still on natural resources and cultural richness, as well as relatively low cost. Several related sectors that have the potential to hamper industries that are still in the stage of revamping, such as hygiene and health. This is evident in terms of natural resources enriched with various fauna and world heritage Indonesia is ranked 6th. In terms of competitive prices, Indonesia's tourism ranked 9th. However, Indonesia's unsatisfactory ranking is in terms of tourism infrastructure (113) And environmental guarantees (125).

The growth of the tourism industry has prompted many countries to continue developing the industry. Indonesia is one of the countries where the development of tourism industry is very rapid. Year 2014 Indonesia managed to capture 9.3 million foreign tourists Visit Indonesia Year program (Martaleni, 2010). Increasing the growth of tourism industry nationally this also affects the growth of tourism in the region. The government strongly supports the tourism industry in the region with the Presidential Regulation No. 19 of 2015 on Tourism. In one article it states that tourism has an important role in expanding and declaring employment opportunities, encouraging regional development, increasing national income in order to improve the welfare and prosperity of the people and fostering the love of the country, enriching the national culture and establishing its guidance in order to strengthen identity Nation and friendship among nations. It is hoped that the tourism sector can become a mainstay sector for each region so that it can promote local revenue and also can expand employment opportunities (Qomariah and Hanafi, 2014).

With increasing competition, all organizations and companies must pay attention to customer loyalty and satisfaction. Satisfied customer then he will re-purchase. With the re-purchase is expected the company can continue the life of the company. Customer satisfaction is a buy-back evaluation where the chosen alternative is at least equal or exceeds the customer's expectation, while dissatisfaction arises when the outcomes do not meet expectations. Comparison between expectations and performance obtained by consumers will produce feelings of pleasure or displeasure. If the performance is in accordance or even exceeded than expected, then consumers will feel happy or satisfied. Conversely, if the performance is in less than expected, then the customer will feel disappointed or not satisfied (Tjiptono, 2005). Satisfaction gained by customers will impact on customer loyalty. Their satisfied customers will re-purchase and will provide good information about the product or service that has provided satisfaction to the customer. Customer loyalty is a deep commitment to buy back or protect a consistent brand or service in the future in a way that leads to the purchase of the same brand or group of brands repeatedly (Tjiptono, 2005).

Many factors can increase customer satisfaction and loyalty. Customer satisfaction and loyalty can increase with customer value. Customer value is the customer's assessment of the product that will be perceived or enjoyed by the customer (Kotler, 2007). Tjiptono (2005) says that customer value is a perceived worth in the monetary unit for a range of economic, technical, service and social benefits in exchange for the price paid for a product. Research that connects customer value with customer satisfaction is research conducted by Dirgantara (2013) which states that partially customer value positively affect the satisfaction of visitors Kartini Museum Jepara. Mardikawati and Farida (2013) stated that customer value can increase customer satisfaction and loyalty.

The next factor that can also affect customer satisfaction is the brand image. Brand image is, is a sign, symbol, name, term or combination used to identify products or services from sellers or groups of sellers that differentiate with products owned by its competitors (Kotler (2008) .The business competition for consumer fighting is no longer limited On product functional attributes such as the benefits or uses of the product, but has been linked to a brand that is capable of providing a distinctive image to the wearer.The use of certain brands of a product can create a sense of pride for the wearer has shifted the brand function as a differentiator with other products (Aaker 1991). The research on brand image and customer satisfaction and loyalty conducted by Suwandi (2015) stated that brand image impacts customer satisfaction but does not affect customer loyalty Qomariah (2012) stated that good institution image can increase student's satisfaction, but institution image can increase customer loyalty. Hidayatullah et al. (2013) also states that brand image can improve customer satisfaction and loyalty. 
Product attributes are also factors that can increase customer satisfaction and loyalty. Product attributes are features that can attract customers. The attributes inherent in the product usually illustrate the seller's perspective (Kotler, 2008). Research Nugroho et al. (2015) suggests that good product attributes can increase customer satisfaction and loyalty. Rahayu (2010) also states that product attributes can increase customer satisfaction.

Customer loyalty is formed with satisfied customers. Satisfied customers mean what they feel is more than what is expected. Kotler (2008) states customer loyalty is something that should be maintained by the service provider, if you want the survival of the company is guaranteed. Research on customer satisfaction and loyalty relationship conducted by Qomariah (2012), Hidayahningtiyas et al (2013), Mardikawati and Farida (2013), Suwandi et al. (2015), Nugroho et al (2015).

Customer loyalty is an act of a customer who repurchases a product or service (Kotler, 2008). Satisfied customers will then redistribute and will also provide good information about the product to other customers. Loyal customers will also recommend the product to others. Zeithaml et al. (1996) stated that the ultimate goal of the company in establishing relationships with its customers is to establish strong loyalty, while indicators of strong loyalty are: 1) Say positive things, is to say something positive about the product consumed. 2) Recommend to someone, is recommending products that have been consumed to friends. 3) Repurchase intention, is a repurchase made on products that have been consumed.

Having a loyal customer is the dream of all brands. But it is not easy to get it. Customers must be made to feel happy when interacting with the company, resulting in satisfaction. Companies must continue to make ways to be able to embrace customers with their own characteristics. Create programs that make customers feel comfortable staying by choosing us. Loyalty and retention are different things. Loyalty is very important but very difficult to measure and monitor loyalty.

According to Kotler (2008) customer satisfaction is the level of one's feelings after comparing the performance (outcome) that compared with expectations. So customer satisfaction is a situation where the wishes, expectations and customer needs can be met. A service is considered satisfactory if the service can meet customer needs and expectations. Measuring customer satisfaction is an important element in providing better, more efficient and more effective service. If the customer is not satisfied with a service provided, then the service can be as ineffective and inefficient. This is especially important for public services. The level of customer satisfaction with service is an important factor in developing a service delivery system that responds to customer needs, minimizes cost and time and maximizes service impacts on target populations.

Kotler and Keller (2008) state that customer value is a combination of quality, service, price of a product offering. The value delivered to the customer is the difference between the amount of value to the customer and the total cost of the customer, and the amount of value to the customer is a group of benefits the customer expects from a particular good or service. Tjiptono (2005) also defines customer value as an emotional bond that exists between customers and producers after customers use the products and services of the company and find that the product or service adds value. Customer value is a benefit that customers get less purchases. Based on this concept, customer value comes from economic benefits, customer benefits, and emotional benefits. The economic bene fi $t$ is derived from price and cost advantages other than the purchase price such as acquisition costs, ownership use, maintenance, and repair and disposal costs. Benefit customers are sourced from the appearance of products, services and reputation. Emotional rewards are the product's superiority in meeting the emotional needs of customers related to psychological needs, customer personality types, and customer personal values.

Brand image is a representation of the overall perception of the brand and is shaped from the past information and experience of the brand (Kotler, 2008). The image of the brand relates to an attitude of belief and preference for a brand. Consumers who have a positive image of a brand will be more likely to make a purchase. Positive consumer image of a brand allows consumers to make purchases. Better brands also form the basis for building a positive corporate image. Understanding the image by Tjiptono (2005) that the image is a set of beliefs, ideas, and impressions, which is owned by a person against an object. The brand includes the knowledge and belief in the brand attribute (cognitive aspect), the consequences of the use of the mark, and the appropriate use 
situation, as well as the evaluations, feelings and emotions associated with the brand (affective aspect). Brand image is defined as consumer perception and brand preference, as reflected by the various brand associations present in consumer memory. Although brand associations can occur in a variety of forms but can be distinguished into performance associations and imagery associations associated with brand attributes and advantages.

Product attributes can give a clear picture of the product itself. In order to give a clear picture about the meaning of this product attribute. Kotler and Armstrong (2008) states that product attributes are the development of a product or service involves determining the benefits to be provided. Understanding product attributes by Tjiptono (2005) is "elements of products that are considered important by consumers and serve as the basis for decision-making". Product attributes include brand, packaging, warranty (guarantee), service, and so on. Product attributes include brands, packaging, labels, warranties or warranties and additional products. Attributes can be viewed objectively or subjectively.

\section{Research Methods}

Population is a generation region consisting of objects and subjects that have certain quantities and characteristics applied in research to be studied and then drawn conclusions (Ferdinand, 2006). The population of this study is the whole of the entire community who have visited coastal attractions that include Papuma Beach, Watu Ulo Beach, Payangan Beach, Puger Beach, and Paseban Beach and Bande Alit Beach. In this study not all populations are used, but in some target populations that can represent it (Ferdinand, 2006). For national research on the various consumer or households have a sample distance of between 200 and 1000 or more. For regional studies it has a sample distance of 50 to 500 or more. The sampling technique used in this research is purposive sampling that is the technique of sampling by using certain purpose according to the criterion specified by the researcher (Ferdinand, 2006). In this study the community to be used as a sample is the people who have visited the existing coastal tourism in Jember Regency which includes Papuma Beach, Watu Ulo Beach, Payangan Beach, Puger Beach, and Paseban Beach and Bande Alit Beach. The number of samples is determined by 300 respondents with the method of sampling is purposive sampling. Each beach resort will be taken as many as 50 respondents. Sample criteria used in this study are respondents who have visited the beach tour twice.

This study is an analytical descriptive research that describes the characteristics of respondents and to test the existing, with a quantitative approach (Ferdinand, 2006). The variables that will be analyzed in this research are variables: customer value, brand image and attribute of customer satisfaction and customer retention. The data validity test is used to test the validity of the measuring instrument used (Ferdinand, 2006). The minimum limit criteria to be considered eligible, ie $r=0.3$. Measurement of reliability is done by measuring the correlation between the answers to the question of using the reliability measuring facility with statistical test Cronbach Alpha $(\alpha)$. A variable will be said to be reliable if it gives Cronbach Alpha value> 0.60 (Arikunto, 2006). Descriptive analysis is used to determine the characteristics of respondents and description of respondents' answers to the indicators of each research variable. The description of each indicator is expressed in the value of frequency and average value (Ferdinand, 2006). To know the influence of each variable of customer value, brand image and product attribute of tourism to customer satisfaction and loyalty individually used regression equation function.

\section{Result and Discussion}

\subsection{Result}

The result of the calculation of descriptive statistic analysis showed that the respondents according to gender consisted of 125 women and 175 men. From the questionnaire distributed it is known that respondents by age consist of less than 20 years old as many as 100 visitors, aged between 21-50 years as many as 175 visitors, aged over 50 years as many as 25 visitors. From the distributed questionnaires it is known that the respondents according to the job consist of 50 civil servants, 
who work as private employees as many as 40 visitors, who work as state employees as many as 25 visitors and who work as student 185 visitors.

The result of validity test shows that all measuring instruments used in this study are valid, because the value of $r$ count is greater than the corrected Item-Total Correlation value of 0.3. For reliability test in this study also shows reliable results for all measuring instruments. This is indicated by the value of cronbach alpha for all variables greater than the required alpha cronbach value of 0.6. The results of multiple linear regression analysis can be seen in Table 1 and Table 2 .

Tabel 1: Result of Multiple Linear Regression Analysis With Visitor Satisfaction As Bound Variable

\begin{tabular}{|c|l|c|c|c|c|}
\hline No. & Variable & Coefisient & P-Value & Alpha & Information \\
\hline 1. & Customer Value $\rightarrow$ Visitor Satisfaction & 0,408 & 0,000 & 0,05 & Significant \\
\hline 2. & Brand Image $\rightarrow$ Visitor Satisfaction & $-0,533$ & 0,000 & 0,05 & Significant \\
\hline 3. & Product Attribute $\rightarrow$ Visitor Satisfaction & 0,345 & 0,000 & 0,05 & Significant \\
\hline
\end{tabular}

Tabel 2: Results of Multiple Linear Regression Analysis With Visitor Loyality As Bound Variable

\begin{tabular}{|c|l|c|c|c|c|}
\hline No. & Variable & Coefisient & P-Value & Alpha & Information \\
\hline 1. & Customer Value $\rightarrow$ Visitor Retention & 0,041 & 0,577 & 0,05 & Significant \\
\hline 2. & Brand Image $\rightarrow$ Visitor Retention & 0,277 & 0,000 & 0,05 & Significant \\
\hline 3. & Product Attribute $\rightarrow$ Visitor Loyality & 0,225 & 0,000 & 0,05 & Significant \\
\hline & Visitor Satisfaction $\rightarrow$ Visitor Loyality & $-0,131$ & 0,007 & 0,05 & Significant \\
\hline
\end{tabular}

\subsection{Discussion}

\subsubsection{The Effect of Customer Value on Satisfaction and Visitor Loyalty}

Based on the results of hypothesis testing it is known that customer value has a positive and significant effect on visitor satisfaction. According to Kotler and Keller (2008) states that customer value is a combination of quality, service, price of a product offering. This means that the better the value of customers from the existing coastal attractions in Jember, the higher the value of satisfaction received by visitors. To realize a good customer value that leads to customer satisfaction, the existing coastal attractions in Jember district can identify the characteristics of customers so as to understand the level of perception and their expectations of customer value. Customer satisfaction and loyalty is formed through the comparison between expectations with perceptions of customer value from coastal resorts in Jember District is perceived. This study is in line with Dirgantara (2013) which states that partially the value of customers positively affect the satisfaction of visitors Kartini Museum Jepara. Mardikawati and Farida (2013) stated that customer value can increase customer satisfaction and loyalty.

\subsubsection{The Influence of Brand Image Against Visitor Satisfaction and Loyalty}

Based on the results of hypothesis testing has proved there is influence between the brand image to visitor satisfaction. This is in line with that expressed by Kotler (2008) which states that the brand image is a representation of the overall perception of the brand and is shaped from the past information and experience of the brand. Theoretically can be proved by Kotler (2008) theory which states that customer perception about brand image formed by existence of information and experience obtained by customer. The research on brand image and customer satisfaction and loyalty done by Suwandi (2015) stated that brand image impact to customer satisfaction but does not affect customer loyalty. Qomariah (2012) stated that good institutional image can increase student's satisfaction, but institutional image can not increase customer loyalty. Hidayatullah et al. (2013) also states that brand image can improve customer satisfaction and loyalty. 


\subsubsection{The Effect of Product Attributes on Satisfaction and Visitor Loyalty}

Based on the results of hypothesis testing has proved there is influence between product attribute to visitor satisfaction. Product attributes are features that can attract customers. The attributes inherent in the product usually illustrate the seller's perspective (Kotler, 2008). Kotler and Armstrong (2007) states that product attributes are the development of a product or service involves determining the benefits to be provided. In theory it can be proved that product attributes that can provide benefits to customers will be able to provide more value to customers that can lead to customer satisfaction and loyalty. Research Nugroho et al. (2015) states that good product attributes can increase customer satisfaction and loyalty. Rahayu (2010) also states that product attributes can increase customer satisfaction.

\subsubsection{The Effect of Visitor Satisfaction Against Visitor Loyalty}

Based on the results of hypothesis testing has proved there is influence between visitor satisfaction with visitor loyalty. Customer loyalty is formed with satisfied customers. Satisfied customers mean what they feel is more than what is expected. Kotler (2008) states customer loyalty is something that should be maintained by the service provider, if you want the survival of the company is guaranteed. Research on customer satisfaction and loyalty relationship conducted by Qomariah (2012), Hidayahningtiyas et al (2013), Mardikawati and Farida (2013), Suwandi et al. (2015), Nugroho et al (2015).

\section{Conclusions and Recommendations}

The value of customer influence on the satisfaction of the visitors of coastal tourism in Jember regency. From the results of this study through multiple linear regression analysis, then in order to improve visitor satisfaction, customer value must be continuously improved.

Brand image affect the satisfaction of visitors of coastal tourism in Jember regency. From the results of this study through multiple linear regression analysis, then in order to improve visitor satisfaction, brand image should be improved.

Product attributes affect the satisfaction of visitors of coastal tourism in Jember District. From the results of this study through multiple linear regression analysis, then in order to improve visitor satisfaction, attributes must be continuously improved.

The value of the customer does not affect the loyalty of visitors of coastal tourism in Jember regency. From the results of this study through multiple linear regression analysis, then in order to increase visitor loyalty, customer value must be continuously improved.

Brand image affect the loyalty of coastal tourism visitors in Jember District. From the results of this study through multiple linear regression analysis, then in order to increase visitor loyalty, brand image must be improved.

Product attributes affect the loyalty of visitors of coastal tourism in Jember regency. From the results of this study through multiple linear regression analysis, then in order to increase visitor loyalty, attributes must be continuously improved.

\section{Reference}

Aaker, D. A.(1991). Managing Brand Equity:Capitalising on the Value of Brand Name. The Free Press: New York

Arikunto, Suharsimi. (2006). Prosedur Penelitian Suatu Pendekatan Praktek. Jakarta: Rineka Cipta.

Dirgantara, Wara. (2013). Pengaruh Kualitas Pelayanan Dan Nilai Pelanggan Terhadap Kepuasan Pengunjung Museum Kartini Jepara. Jurusan Manajemen Fakultas Ekonomi Universitas Negeri Semarang.

Ferdinand, Augusty, (2006). Metode Penelitian Manajemen (Pedoman Penelitian Untuk Penulisan Skripsi, Tesis dan Disertasi Ilmu Manajemen)", Badan Penerbit Universitas Diponegoro, Semarang.

Nurullah Hidajahningtyas, Andi Sularso, Imam Suroso.(2013). Pengaruh Citra, Kualitas Layanan Dan Kepuasan Terhadap Loyalitas Pasien Di Poliklinik Eksekutif Rumah Sakit Daerah Dr. Soebandi Kabupaten Jember. JEAM Vol. 12 No. 1 
Kotler, P. dan Keller, K.L. (2008). Manajemen Pemasaran. Edisi Ketiga Belas. Jilid I Jakarta: Erlangga.

Kotler, P. dan Amstrong G. (2008). Prinsip-prinsip Pemasaran. Jilid I. Jakarta: Erlangga.

Kotler, P. (2008). Prinsip-prinsip Pemasaran. Edisi 12. Jilid 1. Jakarta: Erlangga

Martaleni, (2010)., Positioning Daerah Tujuan Wisata Berdasarkan pada Kepuasan, Image dan Loyalitas Konsumen, Disertasi PDIM Pascasarjana Fakultas Ekonomi Universitas Brawijaya, Malang.

Mardikawati, Moro dan Naili Farida. (2013). Pengaruh Nilai Pelanggan Dan Kualitas Layanan Terhadap Loyalitas Pelanggan, Melalui Kepuasan Pelanggan Pada Pelanggan Bus Efisiensi (Studi PO Efisiensi Jurusan Yogyakarta-Cilacap). Jurnal Administrasi Bisnis, Volume 2, Nomor 1, Maret. Hal 64-75.

Nugroho, Nokma Aditya, Suharyono dan Sunarti. (2015). Pengaruh Atribut Produk Terhadap Kepuasan Pelanggan Dan Loyalitas Pelanggan (Survei Pada Counter Perdana Di Gresik). Jurnal Administrasi Bisnis (JAB)|Vol. 20 No. 1 Maret.

Qomariah, Nurul dan Hanafi, (2014)." Model Peningkatan Kepuasan Pengunjung Berbasis Customer Value : Studi Pada Pegunjung Pantai Watu Ulo dan Pengunjung Pantai Papuma di Kabupaten Jember ". Prosiding Seminar Nasional. Fakultas Ekonomi Universitas Muhammadiyah Surakarta. Mei.

Qomariah, Nurul. (2012). Pengaruh Kualitas Layanan dan Citra Institusi terhadap Kepuasan dan Loyalitas Pelanggan (Studi pada Universitas Muhammadiyah di Jawa Timur). Jurnal Aplikasi Manajemen, Vol. 10 No. 1 Maret. Hal. 177-187.

Rahayu, Agus, (2010). Pengaruh Atribut Produk Wisata Terhadap Kepuasan Wisatawan. Trikonomika Volume 9, No. 2, Desember Hal. 124-130

Suwandi, Andi Sularso, dan Imam Suroso. (2015). Pengaruh Kualitas Layanan, Harga Dan Citra Merek Terhadap Kepuasan Dan Loyalitas Pelanggan Pos Ekspres Di Kantor Pos Bondowoso Dan Situbondo, JEAM Vol XIV April 2015.

Tjiptono, Fandy. (2005). Manajemen Jasa, Edisi kedua. Yogyakarta: Andi.

Zeithaml, V. A., and Bitner, M. J. (1996). Services Marketing. McGrawHill. 